LA-14289

Approved for public release;

distribution is unlimited.

Polychlorinated Biphenyls (PCBs) in

Predator and Bottom-Feeding Fish from

Abiquiu and Cochiti Reservoirs in

North-Central New Mexico
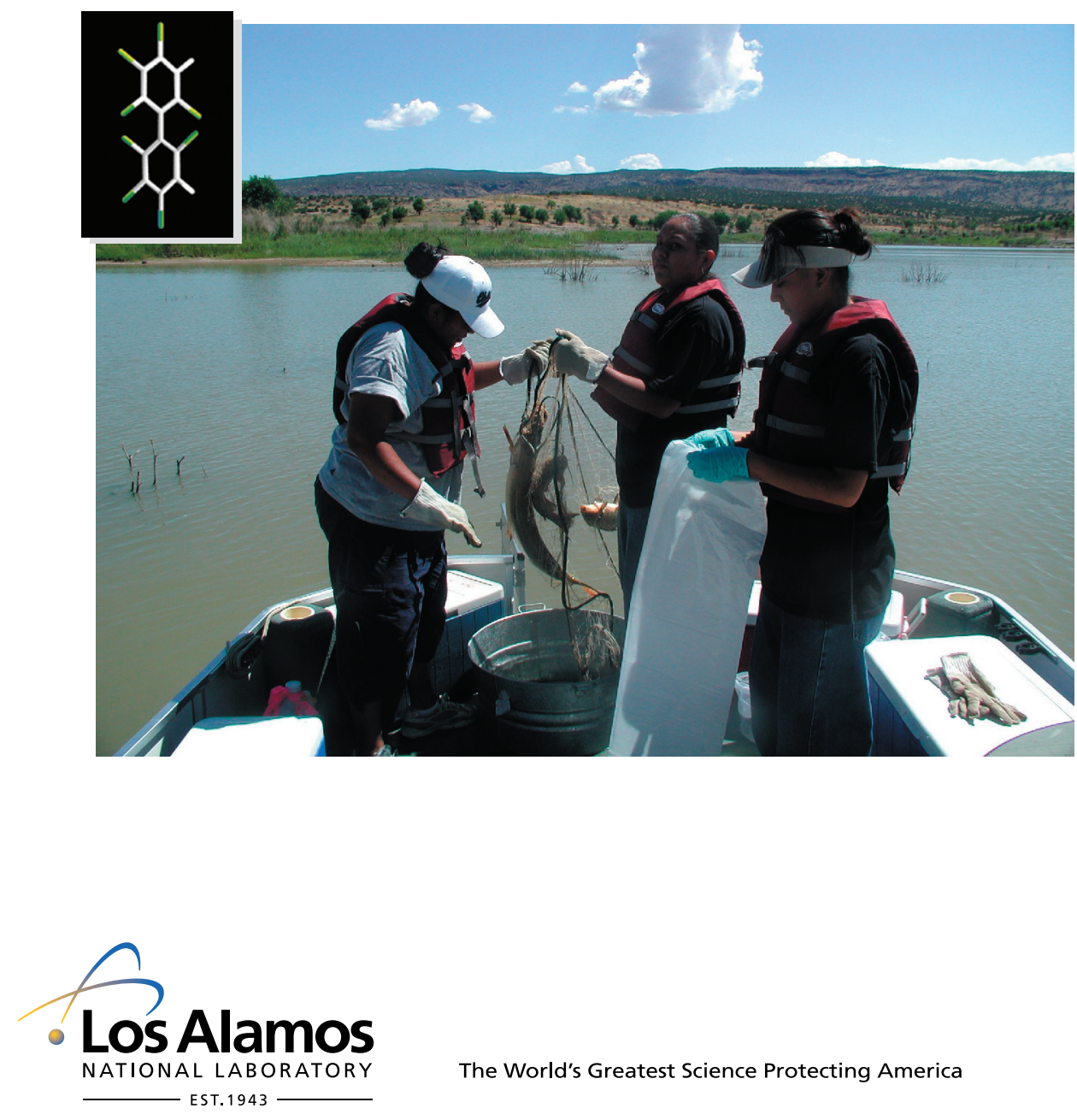

The World's Greatest Science Protecting America 
Edited by Hector Hinojosa, Group IM-1

Front Cover: Left to right, Characteristic biphenyl rings in the chemical structure of PCBs (Flynn 1997) and sampling crew (Glenda Fred, San Ildefonso Pueblo; Cassandra Toledo, Jemez Pueblo; and Victoria Martinez, San Ildefonso Pueblo) using gill nets to collect fish.

Los Alamos National Laboratory, an affirmative action/equal opportunity employer, is operated by the University of California for the United States Department of Energy under contract W-7405-ENG-36.

This report was prepared as an account of work sponsored by an agency of the United States Government. Neither the Regents of the University of California, the United States Government nor any agency thereof, nor any of their employees make any warranty, express or implied, or assume any legal liability or responsibility for the accuracy, completeness, or usefulness of any information, apparatus, product, or process disclosed, or represent that its use would not infringe privately owned rights. Reference herein to any specific commercial product, process, or service by trade name, trademark, manufacturer, or otherwise does not necessarily constitute or imply its endorsement, recommendation, or favoring by the Regents of the University of California, the United States Government, or any agency thereof. The views and opinions of authors expressed herein do not necessarily state or reflect those of the Regents of the University of California, the United States Government, or any agency thereof. Los Alamos National Laboratory strongly supports academic freedom and a researcher's right to publish; as an institution, however, the Laboratory does not endorse the viewpoint of a publication or guarantee its technical correctness. 
LA-14289

Issued: March 2006

Polychlorinated Biphenyls (PCBs) in

Predator and Bottom-Feeding Fish from

Abiquiu and Cochiti Reservoirs in

North-Central New Mexico

G. J. Gonzales

P.R. Fresquez 



\title{
Polychlorinated Biphenyls (PCBs) in Predator and Bottom-Feeding Fish from Abiquiu and Cochiti Reservoirs in North-Central New Mexico
}

\author{
G.J. Gonzales and P.R. Fresquez
}

\begin{abstract}
Concern has existed for years that the Los Alamos National Laboratory (LANL), a complex of nuclear weapons research and support facilities, has released polychlorinated biphenyls (PCBs) to the environment that may have reached adjacent bodies of water through canyons that connect them. In 1997, we began measuring PCBs in fish in the Rio Grande upstream and downstream of ephemeral streams that cross LANL and later began sampling fish in Abiquiu and Cochiti reservoirs, which are situated on the Rio Chama and Rio Grande upstream and downstream of LANL, respectively. In 2005, six species of fish from Abiquiu and Cochiti reservoirs were collected and the edible portion (fillets) was analyzed for 209 possible PCB congeners. Fish from the reservoirs were last sampled in 2001. Mean total PCB concentrations in fish from Abiquiu Reservoir $(\mu=2.4$ $\mathrm{ng} / \mathrm{g})$ were statistically similar $(\alpha=0.01 ; \mathrm{P}(\mathrm{T} \leq \mathrm{t})$ [range $=0.23-0.71])$ to mean total PCB concentrations in fish from Cochiti Reservoir $(\mu=2.7 \mathrm{ng} / \mathrm{g})$, implying that LANL is not the source of PCBs in fish in Cochiti Reservoir. The levels of PCBs in fish from Cochiti Reservoir generally appear to be declining, at least since 2001, which is when PCB levels might have peaked resulting from storm water runoff after the Cerro Grande Fire. Although a PCB "fingerprinting" method can be used to relate PCB "signatures" in one area to signatures in another area, this method of implicating the source of PCBs cannot be effectively used for biota because they alter the PCB signature through metabolic processes. Regardless of the source of the PCBs, certain species of fish (catfish and carpsuckers) at both Abiquiu and Cochiti reservoirs continue to harbor levels of PCBs that could be harmful to human health if they are consistently eaten over a long period of time. Bottom-feeding fish (carpsucker and catfish) from Cochiti Reservoir contained statistically higher levels of total PCBs ( $\mu=4.25 \mathrm{ng} / \mathrm{g}$-filletwet) than predator fish (walleye, northern pike, bass) $(\mu=1.67 \mathrm{ng} / \mathrm{g})$ and the bottom-feeding fish had levels of PCBs that fall into a restricted consumption category in U.S. Environmental Protection Agency (EPA) charts. Similarly, bottom-feeding fish from Abiquiu Reservoir also contained statistically higher levels of total PCBs $(\mu=4.25 \mathrm{ng} / \mathrm{g}$-wet) than predator fish (walleye, bass) ( $\mu=0.68 \mathrm{ng} / \mathrm{g}$-wet) and only the bottom-feeding fish had levels of PCBs that fall into a restricted consumption category in the EPA charts.
\end{abstract}




\section{Introduction and Background}

The Los Alamos National Laboratory (LANL) in northern New Mexico is situated adjacent to and upslope of the Rio Grande, which feeds Cochiti Reservoir to the south of LANL (Fig. 1). With LANL having approximately 19 ephemeral streams in canyons that culminate at the Rio Grande (confluences) there is potential for LANL to discharge into the Rio Grande and, indirectly, Cochiti Reservoir. Like many other industrial sites, LANL historically used devices containing polychlorinated biphenyls (PCBs), such as electrical transformers, and unanticipated releases into the environment may have occurred. Department of Energy (DOE) Orders 450.1 and 5400.5 mandate the monitoring of foodstuffs at and around DOE sites in order to protect humans and ecosystems from contaminants (USDOE 1993; 2003). With the Rio Grande and Cochiti Reservoir serving as important recreational fisheries in north-central and central New Mexico, concern has existed for years that LANL has released PCBs into the environment that may have reached these two bodies of water.

From 1997 to the present, we have sampled fish and artificial fish fat from the Rio Grande and Cochiti and Abiquiu reservoirs and analyzed various fish tissues for PCBs (Gonzales et al. 1999; LANL 2000, 2001; Gonzales and Fresquez 2003; Gonzales and Montoya 2005). The studies were conducted with the intent of assessing (1) potential effects to both nonhumans and humans that consume the fish and (2) whether LANL has contributed to the PCB burdens. Generally, more risk to humans has been identified than to nonhumans on the basis of comparing concentrations of PCBs in fish to human consumption guidance by the U.S. Environmental Protection Agency (EPA) and to PCB intake benchmarks for piscivores. Depending on fish species, some cases have shown concentrations of PCBs in fish upstream of LANL to be higher than downstream of LANL, and in other cases the reverse has been true.

Regardless of their source we continue to periodically monitor PCB concentrations in fish at the adjacent water bodies because of the potential risk to human health posed by fish consumption and the requirements to monitor, at least infrequently. In the summer of 2005 we collected six species of fish with two different feeding strategies from Abiquiu and Cochiti reservoirs and analyzed the fish for PCBs.

\section{Methods}

In August 2005, fish of six different species were captured with gill nets and fillets were removed and submitted for analysis for 209 PCB congeners. This represents the first sampling and analysis of fish for PCBs from these reservoirs since 2001. We sampled predator fish-northern pike (Esox lucius), smallmouth bass (Micropterus dolomieui), white bass (Morone chrysops), and walleye (Stizostedion vitreum) — and bottom-feeding fish-carpsucker (Carpiodes carpio) and channel catfish (Ictalurus punctatus). All fish kept for analysis were mature adults and physical characteristics were recorded.

Analytical Method. The fish were filleted (leaving the skin on) and frozen, and the fillets were submitted for analysis to Alta Analytical, Inc., in California under chains of custody. Fillet samples were homogenized and analyzed for 209 possible congeners of PCBs using EPA Method 1668A-high-resolution gas chromatography (GC) and high-resolution mass spectrometry (MS). Reporting limits (the level above which an analyte can be quantified with confidence) ranged from $0.3-16.1 \mathrm{pg} / \mathrm{g}$ (parts per trillion [ppt]) and the mean reporting limit was $2.6 \mathrm{ng} / \mathrm{g}$ (ppt). Method 1668 also includes lipid analysis using a gravimetric technique that includes the use of dichloromethane as an extraction solvent. Fillet tissue PCB concentrations 


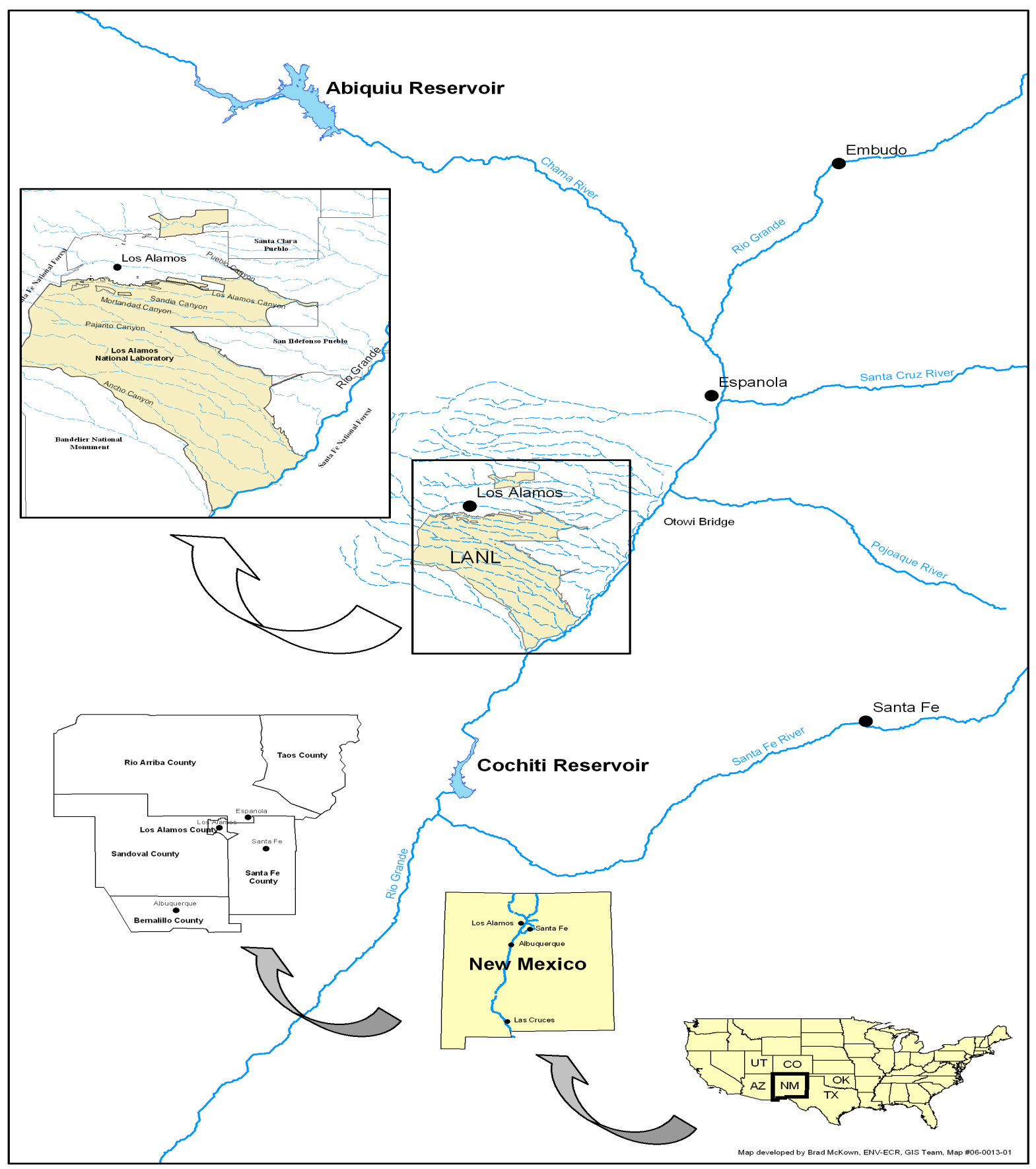

Figure 1. Location of Abiquiu and Cochiti reservoirs in relation to LANL. Also shown, canyon intersections of LANL and Rio Grande. 
were lipid-normalized in order to eliminate the influence on PCB concentrations of the variation in lipid content (and associated physical characteristics) from certain comparisons.

Focused Data Validation. The analytical results were validated following the procedure for GC/MS analysis of organic compounds described in SOP-15.02, R1, Routine Validation of Semi-Volatile Organic Data (LANL/ER 2001). All electronic results were verified against the hard copy data package to ensure $100 \%$ accuracy of the reporting. The analytical results had no data quality issues associated with them, although three congeners were qualified as undetected due to the presence of laboratory blank contamination.

Comparison of Reservoirs as a Means of Indicating LANL Contribution of PCBs. To assess the possible contribution by LANL to PCBs in fish, we made within-species statistical comparisons of total PCBs in Cochiti Reservoir (downstream of LANL confluences with the Rio Grande) with that of Abiquiu Reservoir (upstream of LANL confluences with the Rio Grande). Within each species we conducted two-sample (Abiquiu vs Cochiti) Student t-tests assuming equal variances. We used a $99.9 \%(\alpha=0.01)$ confidence level and compared the computed tvalues to two-tail critical values because the Cochiti Reservoir means could be either higher or lower than the Abiquiu Reservoir means.

Trend. To assess trend in PCB concentrations in fish, we compared the current data to data from previous years and we plotted mean total PCB concentrations in bottom-feeder fish from the Rio Grande and Abiquiu and Cochiti reservoirs over time. In order to do this we (1) compared total PCBs from Aroclor summations to total PCBs from congener summations; (2) extrapolated from whole-body total PCBs to total PCBs in fillet tissue; and (3) extrapolated from total dioxin-like PCBs to total PCBs from 209 congeners. Because there was so much extrapolation necessary to compare PCB totals from different years, we also plotted dioxin-like PCBs over time. This eliminated some of the extrapolation and is also important because toxicity from the dioxin-like PCBs tends to dominate risk. A declining pattern of PCB concentrations in fish from the Rio Grande and, especially Cochiti Reservoir, are expected because there may have been an influx of PCBs into Cochiti Reservoir in 2000 resulting from runoff after the Cerro Grande Fire in May of 2000. This included runoff from the city of Los Alamos.

Homologue Distribution (PCB 'Fingerprinting') as a Means of Indicating Aroclor Parent. To obtain information about the dominant PCBs absorbed and stored by the fish, we summed congener concentrations into PCB homologues (groups of biphenyls with the same number of chlorine atoms). Comparisons of homologue distribution between fish and brandname formulations can give an indication of the original parent PCB mixture (Aroclor). Although knowledge of the predominant Aroclor type or types in the LANL environment might lead to comparisons of similarities and dissimilarities that can implicate source, fish and other biota can selectively store the higher-chlorinated PCB congeners more than lower-chlorinated congeners and degrade other congeners making them subject to elimination from the body. That is, biota can skew the original Aroclor homologue patterns, or "fingerprints," such that the makeup of a PCB mixture in a fish is different than the pattern that they ingested (Sather et al. 2001). Therefore, the use of PCB fingerprinting in fish or other biota to implicate possible source can be misleading.

Effect of Feeding Strategy. For many years we collected bottom-feeding fish such as carpsuckers and catfish for PCB analysis assuming that this was a "conservative" (upper) representation of $\mathrm{PCB}$ concentrations that a consumer of fish might be exposed to. That is, we believed that the feeding strategy of bottom-feeders resulted in the highest exposure to PCBs and, consequently, higher body burdens of PCBs than predator fish. The importance of this 
assumption was that our considerations of EPA-recommended fish consumption limits and risk were assumed to be the most protective of fish consumers. To test this theory this year we sampled both predatory and bottom-feeding fish and compared their PCB levels statistically.

Potential Health Risk from Fish Consumption. To assess the potential risk of consuming PCB-contaminated fish, we summed the total PCB congener concentrations and compared them to EPA risk-based fish consumption limit tables (USEPA 2000). We also calculated dioxin toxicity equivalency quotients (TEQ) and compared total TEQs to the EPA risk-based fish consumption limit tables for dioxins. Some structurally related aromatic hydrocarbons, such as the 12 dioxin-like PCBs and dioxins, invoke a number of common toxic responses. The relative toxicity or potency of the 12 dioxin-like PCBs compared with the toxicity of tetrachlorodibenzodioxin (TCDD) is known. On this basis, the World Health Organization has developed TCDD equivalency factors (TEFs) for the 12 congeners and a method by which their toxicity can be assessed. To evaluate the dioxin-like toxicity that PCBs can cause, the concentration of each congener in the tissue was multiplied by a TEF (Van den Berg et al. 1998), and the 12 resulting values were summed, resulting in a total TEQ. The TEQ can then be used in a number of ways such as comparison with a screening value or other benchmarks for TCDD. The 12 dioxin-like PCB congeners are PCB No. 77 (3,3',4,4'-TeCB), 81 (3,4,4',5-TeCB), 105 (2,3,3',4,4'-PeCB), 114 (2,3,4,4',5-PeCB), 118 (2,3',4,4',5-PeCB), 123 (2',3,4,4',5-PeCB), 126 (3,3',4,4',5-PeCB), 156 (2,3,3',4,4',5-HxCB), 157 (2,3,3',4,4',5'-HxCB), 167 (2,3',4,4',5,5'HxCB), 169 (3,3',4,4',5,5'-HxCB), and 189 (2,3,3',4,4',5,5'-HpCB). TEQs from dioxins and other dioxin-like chemicals should also be added to PCB-based TEQs; however, we have previously shown the TEQ contribution from dioxins and furans to be insubstantial (Fresquez et al. 2002).

\section{Results and Discussion}

Comparison of Reservoirs as a Means of Indicating LANL Contribution of PCBs. Table 1 has a summary of total PCBs by sample for each reservoir and Table A1 in the Appendix has associated fish physical and percent lipid information. Total PCB concentration per unit fillet tissue and per unit lipid are presented. Fillet tissue PCB concentrations were lipid-normalized in order to eliminate the influence on PCB concentrations of the variation in lipid content (and associated physical characteristics) from certain comparisons. The correlation coefficient (r) for concentrations of total PCBs $\times$ percent lipid for the Abiquiu data is 0.88 and for the Cochiti data is 0.33 . We believe that the lipid determination was accurate for the Abiquiu fish but, based on a historical comparison of lipid data, the lipid data for the Cochiti fish was most likely inaccurate. Therefore, although the lipid-normalized data are presented in the appendix, they were not a basis for any of our conclusions.

Statistical comparisons of total PCB concentrations between the two reservoirs (holding species constant) were made for both fillet tissue raw data and fillet tissue lipid-normalized data. Figure 2 shows within-species comparisons of mean total PCBs for fillets at the two locations and the variation (standard deviation) around each mean. The mean total PCB concentration was higher at Abiquiu Reservoir than at Cochiti Reservoir for carpsucker and the reverse was true for catfish, walleye, and bass, however no statistical differences $(\alpha=0.01)$ were detected in total PCB concentrations between the two reservoirs. The high variation around the means, usually caused by one of three fish, played a role in the statistical result. The statistical similarity in PCBs upstream and downstream of LANL has also been observed in some of our previous data on fish as well as in semi-permeable membrane devices (SPMDs), also known as "fat bags" (Gonzales and Montoya 2005). 
Table 1. Summarized Data on PCBs in Fish at Abiquiu and Cochiti Reservoirs. Values are total PCB concentrations (ng/g-fillet [ppb]).

\begin{tabular}{|c|c|c|c|c|c|c|c|c|c|}
\hline & \multicolumn{2}{|c|}{$\underline{\text { Carpsucker }}$} & \multicolumn{2}{|c|}{$\underline{\text { Catfish }}$} & \multicolumn{2}{|c|}{ Walleye } & $\begin{array}{l}\text { Small- } \\
\text { mouth } \\
\underline{\text { Bass }}\end{array}$ & $\begin{array}{l}\text { White } \\
\text { Bass }\end{array}$ & $\begin{array}{c}\text { Northern } \\
\text { Pike }\end{array}$ \\
\hline Rep. No. & Abiquiu & Cochiti & $\underline{\text { Abiquiu }}$ & Cochiti & $\underline{\text { Abiquiu }}$ & Cochiti & Abiquiu & Cochiti & $\underline{\text { Cochiti }}$ \\
\hline 1 & 2.33 & 4.32 & 2.02 & 1.54 & 0.64 & 1.43 & 0.49 & 3.47 & 2.11 \\
\hline 2 & 4.91 & 4.42 & 3.64 & 1.48 & 0.78 & 2.20 & & 1.81 & 0.71 \\
\hline 3 & 8.34 & 3.09 & 4.23 & 10.67 & 0.83 & 0.60 & & 1.79 & 0.90 \\
\hline Mean & 5.20 & 3.94 & 3.30 & 4.56 & 0.75 & 1.41 & 0.49 & 2.36 & 1.24 \\
\hline Std. Dev. & 3.02 & 0.74 & 1.14 & 5.29 & 0.10 & 0.80 & & 0.96 & 0.76 \\
\hline $\begin{array}{c}\text { Comparison } \\
\text { Data }\end{array}$ & & & & & & $\begin{array}{c}6.23 \\
(2002)^{1}\end{array}$ & & & $\begin{array}{c}24.26 \\
(2000)^{2}\end{array}$ \\
\hline
\end{tabular}

${ }^{1}$ Source: NMED (2006). Value is a mean from two fillet samples collected in Cochiti Reservoir.

${ }^{2}$ Source: NMED (2006). Value is from a fillet sample collected from a 9-10 lb fish collected in Cochiti Reservoir.

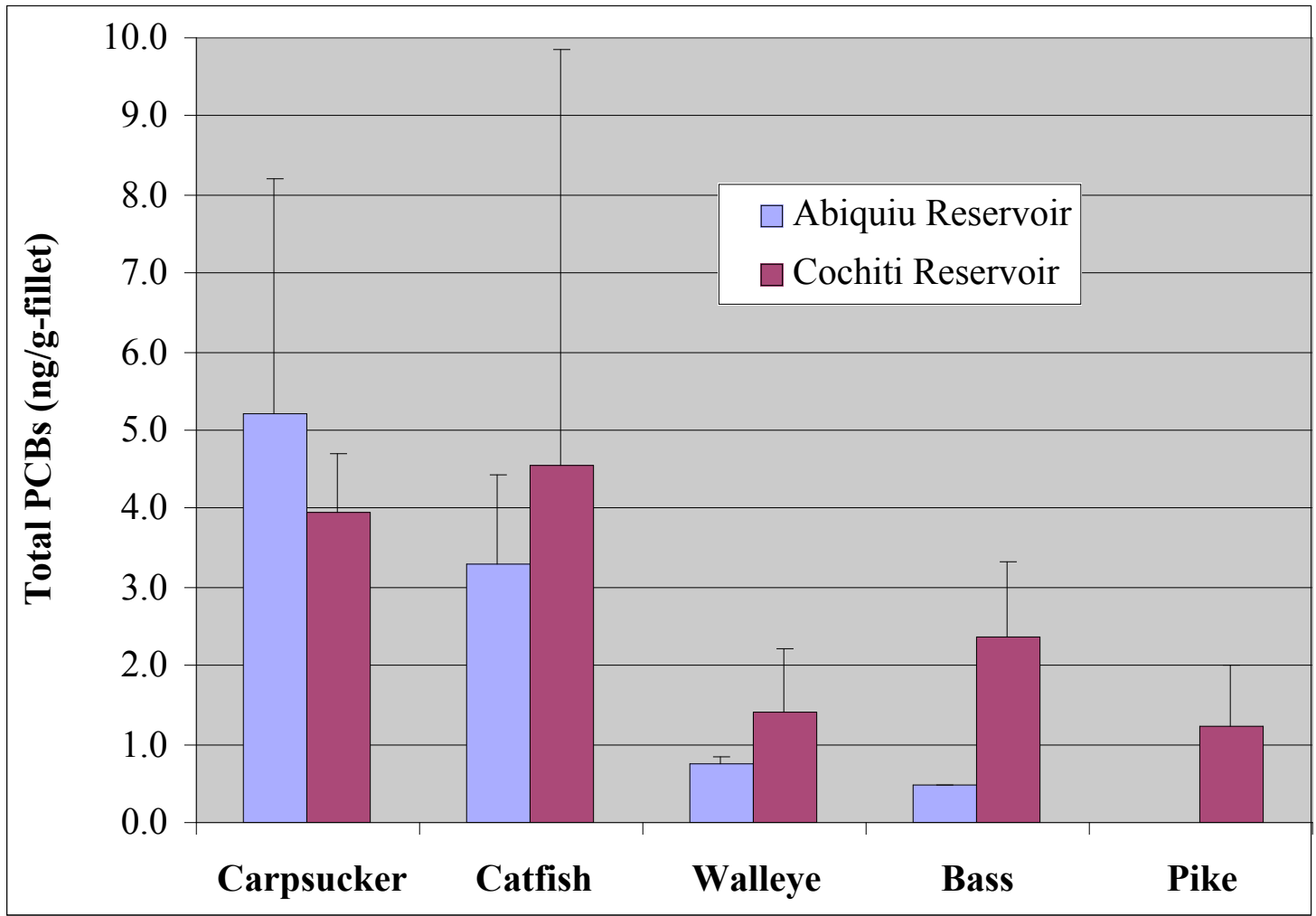

Figure 2. Mean total PCB concentration in fish at Abiquiu and Cochiti reservoirs. (Error bars are +1 standard deviation.) 
Trend. Figure 3 shows mean total PCB concentrations in fillets of bottom-feeding fish and one SPMD from the Rio Grande and Abiquiu and Cochiti reservoirs over time. There appears to be a general decline in concentration of total PCBs over time, although the comparisons are crude because of differences in type of aquatic systems (river vs reservoirs), fish species, analytical methods (EPA Method SW8081 for Aroclors vs EPA Method 1668A for congeners), tissue types (whole body vs fillet) and targeted congeners (12 dioxin-like PCBs vs 209 full-congener suite). There might have been an influx of PCBs into Cochiti Reservoir in 2000 resulting from runoff after the Cerro Grande Fire; therefore, current PCB levels in fish are expected to be lower than in the years following the fire. Generally it appears that fish from the Rio Grande contain more PCBs than fish from the reservoirs. The trend in total PCB concentration is approaching levels at which no fish consumption restrictions would be recommended as is discussed in a later section.

Figure 4 shows mean total dioxin-like PCB concentrations in fillets of bottom-feeding fish and SPMDs from the Rio Grande and Abiquiu and Cochiti reservoirs over time. The trend for dioxin-like PCBs - decreasing - is similar to the trend for total PCBs. Although the trend in dioxin-like PCB concentration is decreasing, the threshold below which no fish consumption restrictions are recommended on the basis of the dioxin-like cancer-related endpoints is very low, so it may be some time before concentrations in fish are low enough to have no consumption limits. Potential consumption restrictions are discussed in a later section.

Other comparisons are made in Table 1. Mean total PCB concentrations (from the 209 possible congeners) for predator fish from the years 2000-2002 are generally one order of magnitude higher than in fish collected in 2005.

Homologue Distribution (PCB “Fingerprinting”) as a Means of Indicating Aroclor Parent. Summed chlorinated biphenyl (CB) or PCB homologues for each fish sample were compared to the homologue distribution of brand-name formulations in an attempt to gain information about the dominant PCB absorbed and stored by the fish. Plots of the homologue distributions (as percentage of total) and of various Aroclor-brand PCB mixtures are shown in Figure 5. Accumulation of PCBs by all fish species at both reservoirs appears to have been dominated by Aroclor 1260 because the peak homologue contribution is at the hexa-CBs (Fig. 5a). Aroclor 1260 has been identified in Sandia Canyon at LANL, and several Aroclors have been detected and quantified in different species and classes of biota sampled from LANL. Since fish from both reservoirs, upstream and downstream of LANL, appear to have contained Aroclor 1260, then LANL (at least Sandia Canyon) is either not the likely source or not the only source. Samples of water from the Rio Grande collected in 2002 did not appear to contain Aroclor 1260 (Mullen and Koch 2002, 2004), which differ from our results on fish. This is evidence that the fish that we sampled and their prey most likely selectively stored and altered (enriched and/or excluded) the homologue distribution that originally existed in their aqueous environment.

Effect of Feeding Strategy. For many years we collected bottom-feeding fish such as carpsuckers and catfish for PCB analysis assuming that their feeding strategy resulted in the highest exposure to PCBs and, consequently, higher body burdens of PCBs than predator fish, that can biomagnify PCBs. The importance of this assumption was that our considerations of EPA-recommended fish consumption limits and risk were assumed to be the most protective by sampling bottom-feeders. At both Cochiti and Abiquiu reservoirs, fillets of bottom-feeding fish contained more total PCBs than predator fish. Bottom-feeding fish from Cochiti Reservoir contained an average of $4.25 \mathrm{ng} / \mathrm{g}$-fillet (wet) total PCBs compared with $1.67 \mathrm{ng} / \mathrm{g}$ for predator 


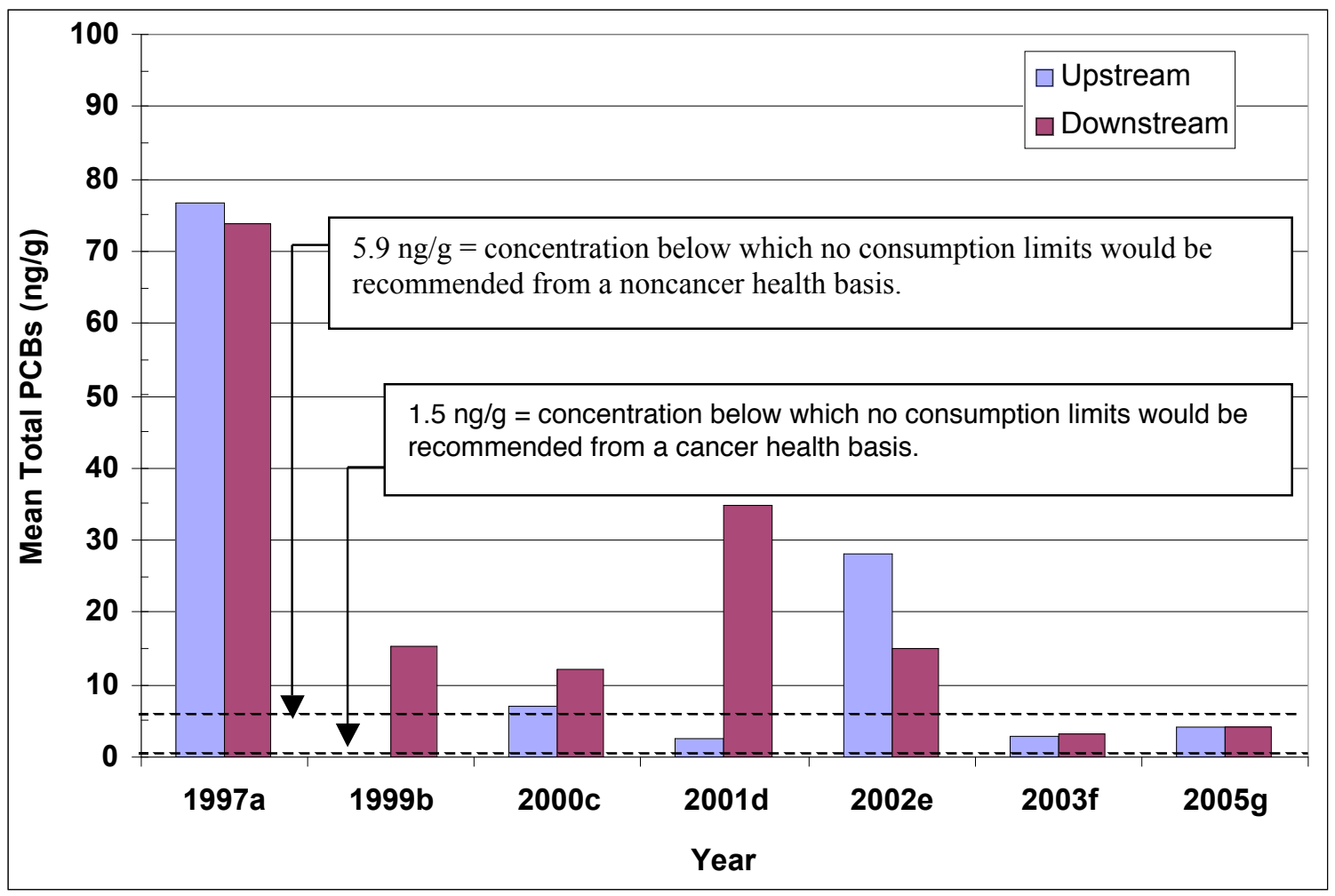

Figure 3. Mean total PCB concentrations (from 209 congeners possible) in fillets of bottom-feeding fish from the Rio Grande and Abiquiu and Cochiti reservoirs over time.

Upstream: Above LANL confluences ( e.g., Abiquiu Reservoir, Rio Grande above Otowi bridge).

Downstream: Below LANL confluences ( e.g., Cochiti Reservoir, Rio Grande below Otowi bridge).

${ }^{\mathrm{a}}$ Total PCBs from summation of Aroclors from catfish collected from the Rio Grande (Data source: Gonzales et al. 1999).

${ }^{\mathrm{b}}$ Mean total PCBs in fillets was estimated from whole-body concentrations in one catfish and one carp collected from Cochiti Reservoir (Data source: NMED 2006).

${ }^{\mathrm{c}}$ Carp collected from Abiquiu (upstream of LANL) and Cochiti (downstream of LANL) reservoirs; Mean total PCBs from summation of 209 congener analysis; Fillet concentrations estimated from ratio of fillet concentration:whole body concentration establised by LANL (2002) (Data source: LANL 2001).

${ }^{\mathrm{d}}$ Abiquiu and Cochiti reservoirs; Cochiti mean total PCBs estimated for 209 total from dioxin-like total PCBs measured in catfish fillets. Abiquiu mean total PCBs estimated for catfish fillets from whole-body and estimated for 209 total from dioxin-like total (Data source: LANL 2002).

${ }^{\mathrm{e}}$ Rio Grande; Catfish; Mean total PCBs from summation of 209-congener analysis of catfish fillets from the Rio Grande. Ten catfish from four confluences downstream of LANL and five catfish upstream of LANL along San Idelfonso Pueblo (Data source: Gonzales and Fresquez 2003).

${ }^{\mathrm{f}}$ SPMDs, also referred to as "fat bags," consist of a triolein-containing polyethylene membrane tube. SPMDs were placed in the Rio Grande above Otowi bridge (upstream of LANL) and at the confluence of Ancho Canyon (downstream of LANL) for 28-day sampling periods. Similar to fish, SPMDs sample dissolved PCBs. SPMDs were analyzed for 209-congener suite (Data source: Gonzales and Montoya 2005).

${ }^{\mathrm{g}}$ Catfish and carpsuckers taken from Abiquiu (upstream of LANL) and Cochiti (downstream of LANL) reservoirs. Mean total PCBs from summation of 209-congener analysis of fillets (Data source: This report). 


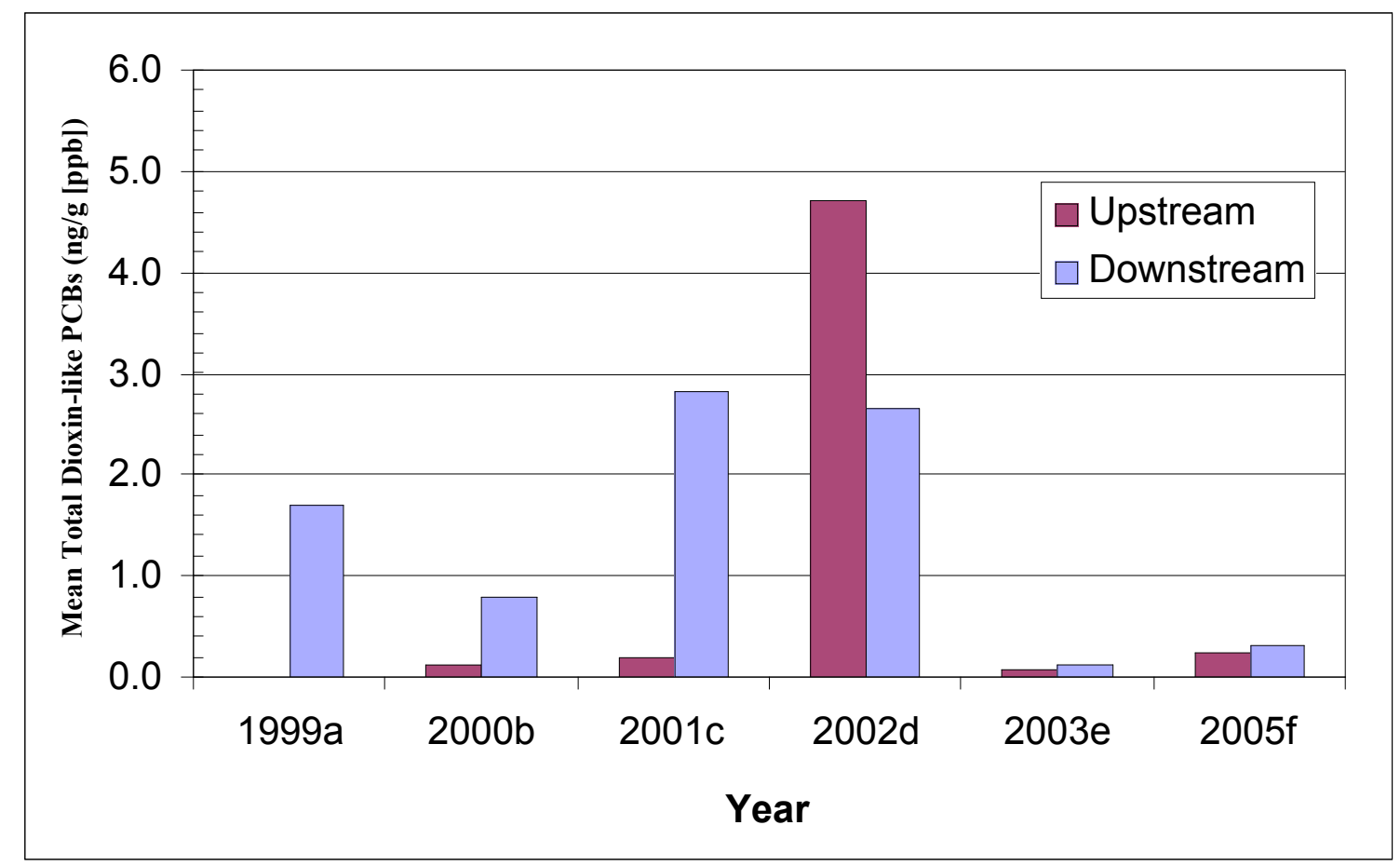

Figure 4. Mean total dioxin-like PCB concentration (ng/g [ppb]) by year in bottom-feeding fish from the Rio Grande and Abiquiu and Cochiti reservoirs.

Upstream: Above LANL confluences ( e.g., Abiquiu Reservoir, Rio Grande above Otowi bridge).

Downstream: Below LANL confluences ( e.g., Cochiti Reservoir, Rio Grande below Otowi bridge).

${ }^{a}$ Cochiti Reservoir (downstream of LANL); Catfish and Carp; Mean total PCBs of 12 dioxin-like congeners in fillets from one catfish and one carp (Data source: NMED 2006). Concentrations in fillets were estimated from whole-body concentrations.

${ }^{\mathrm{b}}$ Abiquiu (upstream of LANL) and Cochiti (downstream of LANL) reservoirs; mean total PCBs of 12 dioxin-like congeners were calculated from multiple catfish and carp (Data source: LANL 2001). Concentrations in fillets were estimated from whole-body concentrations.

${ }^{\mathrm{c}}$ Abiquiu (upstream of LANL) and Cochiti (downstream of LANL) reservoirs; Cochiti mean total dioxin-like PCBs analyzed in fillets. Abiquiu mean total dioxin-like PCB concentrations estimated for fillets from whole body concentrations (Data Source: LANL 2002).

${ }^{\mathrm{d}}$ Rio Grande; Catfish; Mean total PCBs from 12 dioxin-like congeners analyzed in fillet samples. Ten catfish from four confluences downstream of LANL and five catfish upstream of LANL along San Idelfonso Pueblo (Data Source: Gonzales and Fresquez 2003).

"SPMDs, also referred to as "fat bags," were placed in the Rio Grande above Otowi bridge (upstream of LANL) and at the confluence of Ancho Canyon (downstream of LANL) for 28-day sampling periods. Similar to fish, SPMDs sample dissolved PCBs. SPMDs were analyzed for the 12 dioxin-like congeners (Data source: Gonzales and Montoya 2005).

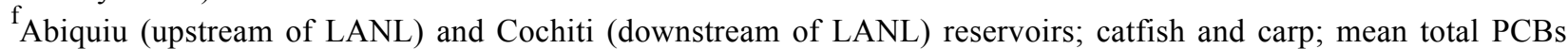
from 12-dioxin like congeners analyzed in fillet samples (Data source: This study). 

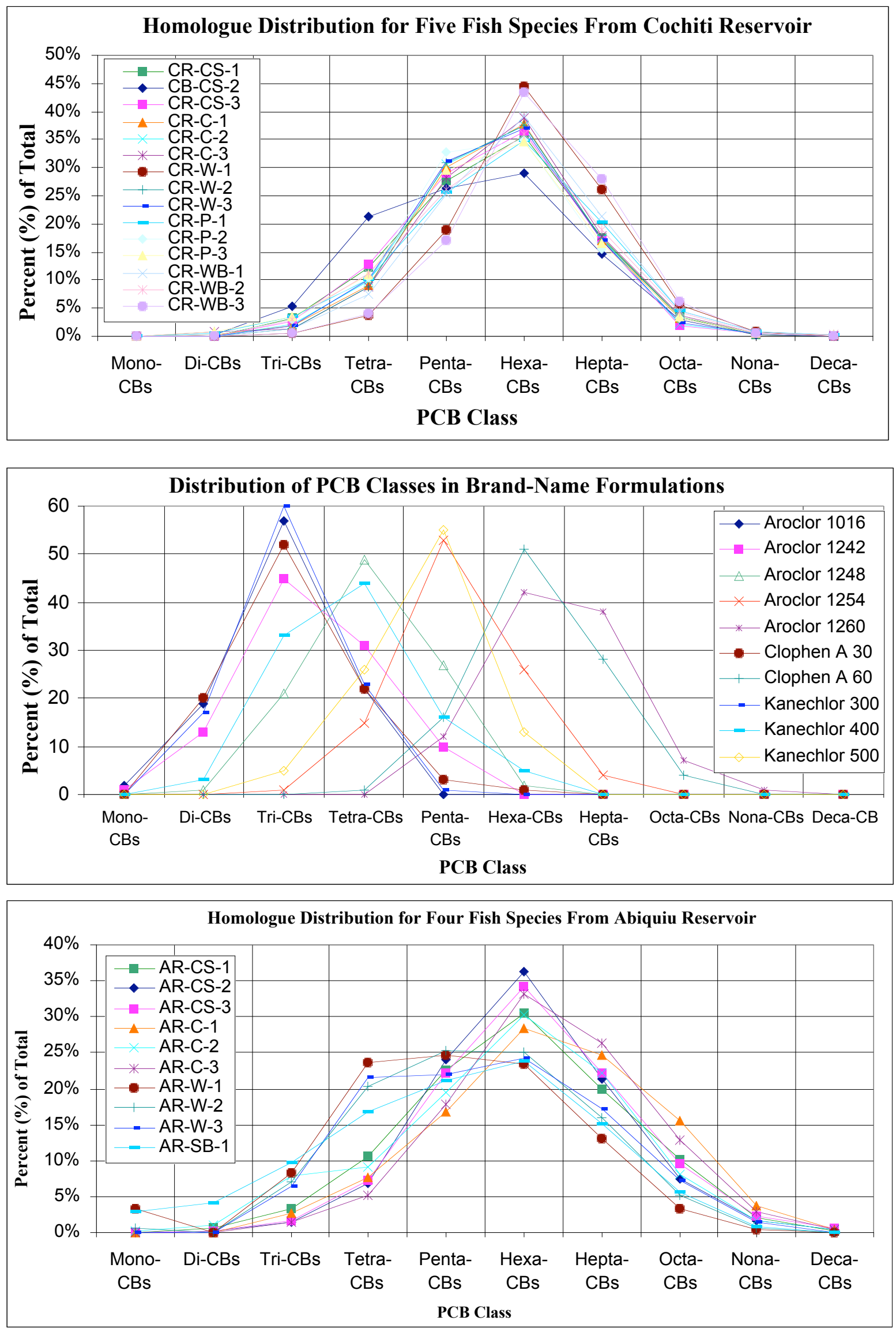

Figure 5. PCB homologue distribution for fish from (a) Cochiti and (c) Abiquiu reservoirs compared with (b) distribution for brand-name formulations. 
fish (Table 2). Bottom-feeding fish from Abiquiu Reservoir contained an average of $4.25 \mathrm{ng} / \mathrm{g}$ fillet (wet) total PCBs compared with $0.68 \mathrm{ng} / \mathrm{g}$ for predator fish. The difference in mean total PCB concentration between bottom-feeding and predator fish was statistically different at both Cochiti $(\mathrm{P}=0.046)$ and Abiquiu $(\mathrm{P}=0.02)$.

\begin{tabular}{|c|c|c|c|c|}
\hline & $\begin{array}{l}\text { Cochiti } \\
\text { Bottom- } \\
\text { Feeders } \\
\end{array}$ & $\begin{array}{l}\text { Cochiti } \\
\text { Predators }\end{array}$ & $\begin{array}{l}\text { Abiquiu } \\
\text { Bottom- } \\
\text { Feeders }\end{array}$ & $\begin{array}{c}\text { Abiquiu } \\
\text { Predators }\end{array}$ \\
\hline & 4.32 & 1.43 & 2.33 & 0.64 \\
\hline & 4.42 & 2.20 & 4.91 & 0.78 \\
\hline & 3.09 & 0.60 & 8.34 & 0.83 \\
\hline & 1.54 & 3.47 & 2.02 & 0.49 \\
\hline & 1.48 & 1.81 & 3.64 & 0.68 \\
\hline & 10.67 & 1.79 & 4.23 & \\
\hline & & 2.11 & & \\
\hline & & 0.71 & & \\
\hline & & 0.90 & & \\
\hline Mean & 4.25 & 1.67 & 4.25 & 0.68 \\
\hline Std. Dev. & 3.4 & 0.90 & 2.29 & 0.15 \\
\hline
\end{tabular}

Potential Health Risk from Fish Consumption. Potential health effects from consuming PCB-laden fish were based on consulting EPA risk-based fish consumption limit tables for both the direct effects of PCBs and equivalency of certain congeners to the toxic effects of dioxin. The results of consulting the EPA tables are shown in Tables 3 and 4. The dioxin-equivalent restrictions are greater than the PCB-based restrictions. For mean total PCBs in catfish, walleye, white bass, pike, and smallmouth bass, the EPA tables recommend no consumption restrictions at either reservoir on the basis of noncarcinogenic (chronic, systemic) health endpoints. On the basis of carcinogenic health endpoints, there would be no consumption restrictions on walleye and pike from Cochiti Reservoir nor for walleye and smallmouth bass at Abiquiu Reservoir. The EPA would recommend limiting consumption of catfish and white bass at Cochiti Reservoir to 8 and 12 8-oz meals per month, respectively. For catfish from Abiquiu the EPA chart would recommend limiting consumption to 12 meals per month. Concerning dioxin-like toxicity and cancer health endpoints, recommended fish consumption restrictions are four, two, and two meals per month for white bass, catfish, and carpsuckers, respectively, from Cochiti Reservoir and one and two meals per month for carpsuckers and catfish, respectively, from Abiquiu Reservoir (Table 4). Note that the EPA recommends that a large set of issues and criteria be studied before considering the issuance of advisories on the restricted consumption of fish from any area. 
Table 3. Potential Monthly Fish Consumption Limits on the Basis of Potential Toxicity from Total PCBs ${ }^{1}$

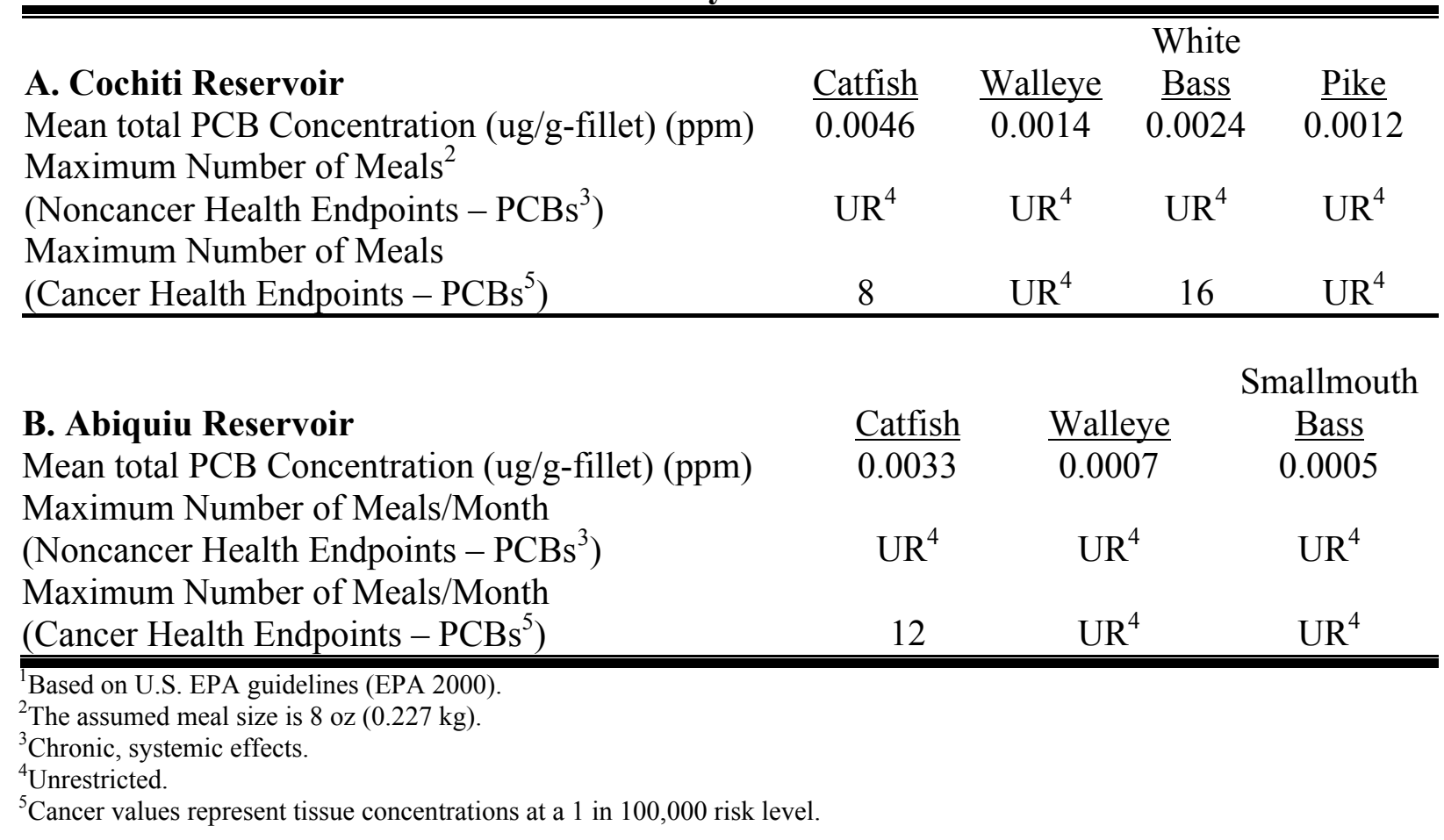

Table 4. PCB Dioxin Toxicity-Equivalency Quotients (pg/g-fillet) (ppt) and Potential Monthly Consumption Limits for Fish from Cochiti and Abiquiu Reservoirs

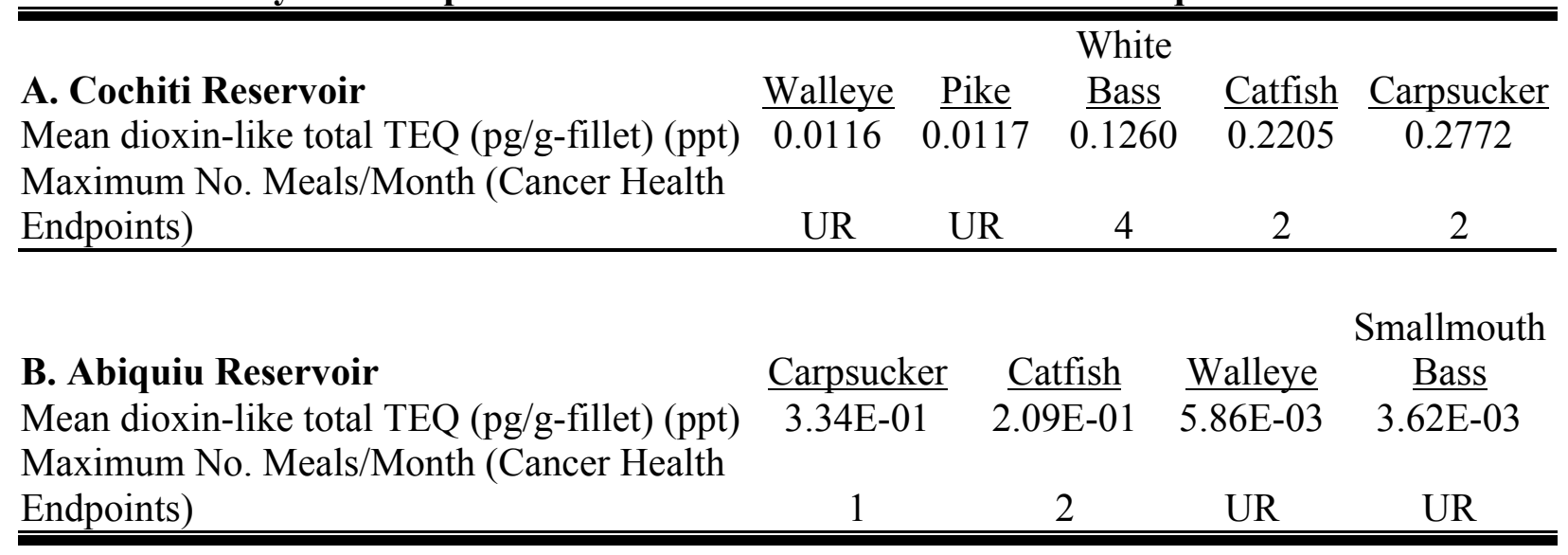




\section{Acknowledgments}

This study was funded by Los Alamos National Laboratory's Environmental Surveillance Program under the U.S. Department of Energy/University of California/Los Alamos National Laboratory contract. Fish were captured and processed by LANL's Soils, Foodstuffs, and Biota Program assisted by the Ecology Group. Karen Schultz Paige of LANL's Meteorology and Air Quality Group validated all data.

\section{Literature Cited}

Flynn, L. T. 1997. Public Health Concerns About Environmental Polychlorinated Biphenyls (PCBs), A Position Paper of the American Council on Science and Health. Academic Press, Burlington MA, USA.

Fresquez P. R., L. Soholt, K. Bennett, and G. J. Gonzales. 2002. Radionuclide Concentrations in Predator and Bottom-Feeding Fish Upstream and Downstream of Los Alamos National Laboratory: 1976 to 2002 (With Special Reference to the La Mesa and Cerro Grande Fires). Los Alamos National Laboratory report LA-13998, Los Alamos, NM.

Gonzales, G. J. and J. T. Montoya. 2005. Polychlorinated Biphenyls (PCBs) in the Rio Grande Sampled Using Semipermeable Membrane Devices ("Fat Bags"). Los Alamos National Laboratory report LA-14200, Los Alamos, NM.

Gonzales, G. J. and P. R. Fresquez. 2003. Polychlorinated Biphenyls (PCBs) in Catfish and Carp Collected from the Rio Grande Upstream and Downstream of Los Alamos National Laboratory. Los Alamos National Laboratory report LA-14001, Los Alamos, NM.

Gonzales, G. J., P. R. Fresquez, and J. W. Beveridge. 1999. Organic Contaminant Levels in Three Fish Species Downchannel from the Los Alamos National Laboratory. Los Alamos National Laboratory report LA-13612-MS, Los Alamos, NM.

LANL (Los Alamos National Laboratory). 2002. Soil, Foodstuffs, and Associated Biota. Pages 421-521 in Environmental Surveillance at Los Alamos during 2001. Fresquez, P., G. Gonzales, J. Nyhan, T. Haarmann, L. Soholt, and B. Gallaher. Los Alamos National Laboratory report LA-13979-ENV, Los Alamos, NM.

LANL (Los Alamos National Laboratory). 2001. Soil, Foodstuffs, and Associated Biota. Pages 407-489 in Environmental Surveillance at Los Alamos during 2000. Fresquez, P., G. Gonzales, T. Haarmann, J. Nyhan, and B. Gallaher. Los Alamos National Laboratory report LA-13861-ENV, Los Alamos, NM.

LANL (Los Alamos National Laboratory). 2000. Soil, Foodstuffs, and Associated Biota. Pages 309-360 in Environmental Surveillance at Los Alamos during 1999. Fresquez, P. R. and G. J. Gonzales. Los Alamos National Laboratory report LA-13777-ENV, Los Alamos, NM.

LANL/ER (Los Alamos National Laboratory/Environmental Restoration). Routine Validation of Semi-Volatile Organic Data. LANL/ER2001-0239, Standard operating procedure SOP15.02, R1.

Mullen, K. and R. Koch. 2002. Personal communication, e-mail from Richard Koch (Science Applications International Corporation) to Ken Mullen (LANL/RRES-WQH) and Gil Gonzales (LANL/RRES-ECO), "PCB Congener - preliminary results," dated Sept. 16, 2002.

Mullen, K. and R. Koch. 2004. PCB Congener preliminary results, 2000-2003 surface water and sediment sampling. Los Alamos National Laboratory report LA-UR-04-0758, Los Alamos, NM. 
NMED (New Mexico Environment Department). 2006. E-mail from Ralph Ford-Schmid (NMED) to Gil Gonzales (Los Alamos National Laboratory), on "PCBs in fish tissue data 1993-2002 6-22-04.xls," dated Jan. 27, 2006.

Sather, P. J., M. G. Ikonomou, R. F. Addison, T. He, P. S. Ross, and B. Fowler. 2001. Similarity of an Aroclor-Based and a Full Congener-Based Method in Determining Total PCBs and A Modeling Approach to Estimate Aroclor Speciation from Congener-Specific PCB Data. Environ. Sci. Technol. 35:4874-4880.

USDOE (U.S. Department of Energy). 1993. Radiation Protection of the Public and the Environment, DOE Order 5400.5. U.S. Department of Energy; Office of Environment, Safety, and Health; Washington D.C.

USDOE (U.S. Department of Energy). 2003. Environmental Protection Program, DOE Order 450.1. U.S. Department of Energy; Office of Environment, Safety, and Health; Washington D.C.

USEPA (U.S. Environmental Protection Agency). 2000. Guidance for Assessing Chemical Contaminant Data for Use in Fish Advisories, Vol. 2: Risk Assessment and Fish Consumption Limits, 3rd Ed., EPA 823-B-00-008.

Van den Berg, M., L. Birnbaum, A. T. C. Bosveld et al. 1998. Toxic Equivalency Factors (TEFs) for PCBs, PCDDs, PCDFs for Human and Wildlife. Environ. Health Perspect. 106(12):775-792. 


\section{Appendix}

\section{Table A1. Physical Characteristics and Total PCB Concentrations in Fish Collected at}

Cochiti and Abiquiu Reservoirs Upstream and Downstream of LANL, Respectively

\begin{tabular}{|c|c|c|c|c|c|c|c|c|c|}
\hline $\begin{array}{c}\text { Date } \\
\text { Sampled }\end{array}$ & $\begin{array}{l}\text { Sample } \\
\text { No. }\end{array}$ & Site & Species & $\begin{array}{l}\text { Weight } \\
\text { (lbs.) }\end{array}$ & $\begin{array}{l}\text { Length } \\
\text { (in.) }\end{array}$ & $\begin{array}{l}\text { Girth } \\
\text { (in.) }\end{array}$ & $\begin{array}{l}\text { Percent } \\
\text { Lipids }\end{array}$ & $\begin{array}{c}\text { Total PCB } \\
\text { Concentra. } \\
\text { (ng/g) in } \\
\text { Fillet }\end{array}$ & $\begin{array}{c}\text { Total PCB } \\
\text { Concentra. } \\
\text { (ng/g) in } \\
\text { Lipid }\end{array}$ \\
\hline $8 / 10 / 2005$ & CR-B-1 & Cochiti & Carpsucker & 2.75 & 16.0 & 10.0 & 3.462 & 4.3 & 12.7 \\
\hline $8 / 10 / 2005$ & CB-B-2 & Cochiti & Carpsucker & 3.00 & 16.0 & 10.0 & 5.370 & 4.4 & 7.9 \\
\hline $8 / 10 / 2005$ & CR-B-3 & Cochiti & Carpsucker & 3.50 & 17.0 & 12.0 & 3.714 & 3.1 & 8.0 \\
\hline $8 / 10 / 2005$ & CR-C-1 & Cochiti & Catfish & 3.25 & 19.0 & 9.0 & 0.224 & 1.5 & 69.8 \\
\hline $8 / 10 / 2005$ & CR-C-2 & Cochiti & Catfish & 3.00 & 18.0 & 9.0 & 0.444 & 1.5 & 33.6 \\
\hline $8 / 10 / 2005$ & CR-C-3 & Cochiti & Catfish & 3.50 & 19.0 & 10.0 & 0.666 & 10.7 & 164.2 \\
\hline $8 / 10 / 2005$ & CR-W-1 & Cochiti & Walleye & 4.50 & 22.0 & 11.5 & 0.177 & 1.4 & 79.6 \\
\hline $8 / 10 / 2005$ & CR-W-2 & Cochiti & Walleye & 3.75 & 22.5 & 11.0 & 0.123 & 2.2 & 183.4 \\
\hline $8 / 10 / 2005$ & CR-W-3 & Cochiti & Walleye & 2.00 & 14.0 & 7.0 & 0.030 & 0.6 & 197.0 \\
\hline $8 / 10 / 2005$ & CR-P-1 & Cochiti & Pike & 6.75 & 30.0 & 11.0 & 0.162 & 2.1 & 131.8 \\
\hline $8 / 10 / 2005$ & CR-P-2 & Cochiti & Pike & 5.75 & 27.5 & 11.0 & 0.128 & 0.7 & 55.0 \\
\hline $8 / 10 / 2005$ & CR-P-3 & Cochiti & Pike & 3.75 & 22.5 & 9.0 & 0.092 & 0.9 & 50.2 \\
\hline $8 / 10 / 2005$ & CR-WB-1 & Cochiti & White Bass & 1.75 & 11.5 & 8.5 & 0.106 & 3.5 & 348.7 \\
\hline $8 / 10 / 2005$ & CR-WB-2 & Cochiti & White Bass & 1.75 & 11.0 & 7.5 & 0.161 & 1.8 & 113.0 \\
\hline $8 / 10 / 2005$ & CR-WB-3 & Cochiti & White Bass & 1.50 & 10.5 & 7.0 & 0.181 & 1.8 & 99.8 \\
\hline Mean & & & & & & & 1.003 & 2.7 & 103.6 \\
\hline $8 / 23 / 2005$ & AR-B-1 & Abiquiu & Carpsucker & 3.00 & 19.0 & 11.0 & 11.498 & 2.3 & 2.0 \\
\hline $8 / 23 / 2005$ & AR-B-2 & Abiquiu & Carpsucker & 4.25 & 21.0 & 12.5 & 7.944 & 4.9 & 6.0 \\
\hline $8 / 23 / 2005$ & AR-B-3 & Abiquiu & Carpsucker & 4.00 & 21.0 & 12.0 & 18.477 & 8.3 & 4.5 \\
\hline $8 / 23 / 2005$ & AR-C-1 & Abiquiu & Catfish & 2.00 & 18.5 & 8.5 & 3.678 & 2.0 & 5.5 \\
\hline $8 / 23 / 2005$ & AR-C-2 & Abiquiu & Catfish & 3.75 & 22.0 & 9.5 & 4.042 & 3.6 & 9.0 \\
\hline $8 / 23 / 2005$ & AR-C-3 & Abiquiu & Catfish & 3.50 & 23.5 & 10.0 & 7.761 & 4.2 & 5.5 \\
\hline $8 / 23 / 2005$ & AR-W-1 & Abiquiu & Walleye & 3.25 & 20.0 & 11.0 & 1.054 & 0.6 & 5.9 \\
\hline $8 / 23 / 2005$ & AR-W-2 & Abiquiu & Walleye & 3.00 & 19.5 & 10.0 & 1.386 & 0.8 & 5.6 \\
\hline $8 / 23 / 2005$ & AR-W-3 & Abiquiu & $\begin{array}{c}\text { Walleye } \\
\text { Smallmouth }\end{array}$ & 2.25 & 18.0 & 10.0 & 1.410 & 0.8 & 15.6 \\
\hline $8 / 23 / 2005$ & AR-SB-1 & Abiquiu & Bass & 2.00 & 15.5 & 9.5 & 1.206 & 0.5 & 4.0 \\
\hline Mean & & & & & & & 5.846 & 2.8 & 6.4 \\
\hline
\end{tabular}


This report has been reproduced directly from the best available copy. It is available electronically on the Web (http://www.doe.gov/bridge).

Copies are available for sale to U.S. Department of Energy employees and contractors from:

Office of Scientific and Technical Information P.O. Box 62

Oak Ridge, TN 37831

(865) 576-8401

Copies are available for sale to the public from: National Technical Information Service

U.S. Department of Commerce

5285 Port Royal Road

Springfield, VA 22161

(800) 553-6847 


\section{Los Alamos}

NATIONAL LABORATORY

EST.1943 